\title{
Assessment of Heavy Metal Contamination in Sediments of the Shitalakhya River, Bangladesh
}

\author{
A N M Al-Razee ${ }^{1,2}$, Md Nurul Abser ${ }^{1}$, Md Abdul Mottalib ${ }^{3}$, Aklima Nargis $^{4}$, \\ Anowara Khanam Jhumur ${ }^{4}$, Md Mostak Uddin Thakur ${ }^{2}$, Wenbin Liu ${ }^{5}$, \\ Sandeep Poddar ${ }^{6}$, Md Shafiqul Islam Sarker ${ }^{7}$ and Ahsan Habib** \\ ${ }^{1}$ Department of Chemistry, Jahangirnagar University, Dhaka-1342, Bangladesh. \\ ${ }^{2}$ Department of Analytical Chemistry \& Environmental Science, \\ Training Institute for Chemical Industries, Polash, Narsingdi, Bangladesh. \\ ${ }^{3}$ Institute of Leather Engineering and Technology, University of Dhaka, Dhaka-1000, Bangladesh. \\ ${ }^{4}$ Department of Chemistry, University of Dhaka, Dhaka-1000, Bangladesh. \\ ${ }^{5}$ State Key Laboratory of Environmental Chemistry and Ecotoxicology, Research Center for Eco-Environmental \\ Sciences, Chinese Academy of Sciences, Beijing 100085, China. \\ ${ }^{6}$ Lincoln University College, Wisma Lincoln, Petaling Jaya 47301, Selangor, Malaysia. \\ ${ }^{7}$ Central Chemical Laboratory, Department of Narcotics Control, Ministry of Home Affairs, \\ Dhaka-1204, Bangladesh. \\ *Corresponding Author Email: al_razee8@yahoo.co.uk \\ Received 26 October 2019, Revised 08 February 2021, Accepted 26 March 2021
}

\begin{abstract}
Sediment samples collected from the river Shitalakhya, Bangladesh, were analyzed using atomic absorption spectroscopy (AAS) to investigate site-to-site (spatial) and seasonal (i.e., dry, premonsoon, post-monsoon) variation of $\mathrm{Cr}, \mathrm{Mn}, \mathrm{Ni}, \mathrm{Cu}$ and $\mathrm{Zn}$. The mean concentrations of $\mathrm{Cr}, \mathrm{Mn}$, $\mathrm{Ni}, \mathrm{Cu}$ and $\mathrm{Zn}$ were $22.37 \pm 6.09,612.59 \pm 160.08,54.11 \pm 11.21,50.36 \pm 9.40$ and $103.62 \pm$ $62.74 \mathrm{mg} / \mathrm{kg}$ in the dry, $31.58 \pm 5.22,569.71 \pm 112.16,58.35 \pm 7.82,49.93 \pm 17.36$ and $110.88 \pm$ $95.83 \mathrm{mg} / \mathrm{kg}$ in the pre-monsoon and $18.09 \pm 6.32,567.02 \pm 115.55,50.89 \pm 6.58,39.75 \pm 4.56$ and $55.22 \pm 11.33 \mathrm{mg} / \mathrm{kg}$ in the post-monsoon, respectively. Based on the metals' concentrations, no considerable difference was observed among the three seasons, but the concentrations were slightly elevated in the dry and pre-monsoon compared to that in the post-monsoon with respect to site-to-site variation. Among the metals examined, concentrations of $\mathrm{Ni}$ and $\mathrm{Cu}$ were elevated because of the use of oxides of these heavy metals as catalysts in the ammonia plant. The following statistical indices i.e., Pearson correlation matrix, geo-accumulation index $\left(I_{\text {geo }}\right)$, contamination factor $\left(C_{\mathrm{f}}\right)$, degree of contamination $\left(C_{\mathrm{d}}\right)$, pollution load index (PLI) and ecological risk potential $\left(R_{\mathrm{I}}\right)$ factors were taken into account to assess the heavy metals contamination of the sediments. According to the values of the statistical indices for $\mathrm{Cr}, \mathrm{Mn}, \mathrm{Ni}, \mathrm{Cu}$ and $\mathrm{Zn}$, it is concluded that the study area was with low contamination while concentrations of $\mathrm{Ni}$ and $\mathrm{Cu}$ were higher than the Threshold Effect Level (TEL) and Toxicity Reference Value (TRV) values suggesting unsafe to use the sediments for vegetation and other uses.
\end{abstract}

Keywords: Heavy Metals, Surface Sediments, Shitalakhya River, Geo-accumulation Index, Pollution Load Index.

\section{Introduction}

Sediment is an essential component of the terrestrial ecosystem of the earth. The suspended colloidal particles in the aquatic system remove various types of chemical 
species including both inorganic and organic pollutants through adsorption process. The fine colloidal particles carry either positive or negative surface charge, thus chemical species with relevant charge can accumulate on the colloidal particles. Consequently, the colloidal particles gain effective mass through accumulation of different chemical species and deposit as sediment at the bottom of the aquatic system. The reactions in soils and sediments even though are comparable, but the top sediment layer of the riverine systems is supposed to be more contaminated. Khan reported that about 2.4 billion tons of sediments transport over the riverine system in Bangladesh every year thus, a part of this huge amount of the sediments deposit in the floodplains [1]. Industrialization and urbanization cause to discharge the toxic chemicals into the environment. Ultimately, the toxic chemicals are being deposited in the sediments. Thus, the deposition of trace elements in the sediments is becoming an alarming issue globally at both private and governmental levels.

The river Shitalakhya plays a vital role by using its water for various purposes such as industry, domestic, agriculture etc for the population of the greater Dhaka division, Bangladesh. There are many small, medium and heavy industries including three Key Point Installation (KPI) of Bangladesh such as two fertilizer industries and the largest thermal power plant, some of them are under red category [2], are situated on the east bank of the Shitalakhya river in Polash-Ghorashal area as shown in Fig. 1. Consequently, the studied area has become contaminated by various industrial pollutants. It has been reported that automobile workshops and other metallurgical units contaminate the groundwater by heavy metals [3]. Generally surface water is used for various purposes in industries such as cooling, steam generation, safety etc. The river
Shitalakhya has been termed as an environmental pollution protected zone by the Dhaka Metropolitan Development Plan (DMDP) [4].



Figure 1. Map of study area (a) and Bangladesh (b).

The present study explores to find out the concentrations of $\mathrm{Fe}, \mathrm{Mn}, \mathrm{Cu}, \mathrm{Zn}, \mathrm{Ni}, \mathrm{Cr}$ in the sediments collected from the banks of the river Shitalakhya that closed to PolashGhorashal industrial area (Fig. 1) to assess the industrial impacts of the heavy metals in the river sediments. The river Shitalakhya is regarded as one of the most polluted rivers in Bangladesh because of direct discharge of industrial wastewater to the river water.

\section{Materials and Methods Sampling Locations and Collection}

Sediment sampling stations were selected based on different types of industries such as fertilizer factories, cement industry (Seven Rings Cement Industries Ltd) and paper mill (Capital Paper Mill) which are located in the Polash-Ghorashal industrial area (as shown in Fig. 1 and Table 1). The fertilizer factories are located at Polash (Fig. 1a, designated as Polash Urea Fertilizer Factory Limited (PUFFL) and Urea Fertilizer Factory Limited (UFFL)). The cement industry and paper mill are located about 10 and $12 \mathrm{~km}$ 
downstream of the river from the fertilizer factories. Sampling was carried out from January to October, 2012 for three seasons namely dry season (January), pre-monsoon (April) and post-monsoon (October). Thirteen sediment samples were collected for each season. Total thirty-nine samples were collected. . At each location, three samples were collected at $0-30 \mathrm{~cm}$ depth from the surface of the riverbanks using a gouge auger. The collected samples were mixed well and the amount was about $500 \mathrm{~g}$. The samples were dried in air and grinded. The crushed samples were sieved using a sieve with $2 \mathrm{~mm}$ pore size to remove large debris, stones and pebbles and then kept in zip-lock plastic bags. Prior to digestion, the samples were kept in an oven at $105{ }^{\circ} \mathrm{C}$ for $2 \mathrm{~h}$ to remove moisture. A porcelain mortar was used to make a homogeneous mixture. The powder sample was then sieved by using 60 mesh sieves. The homogeneous dried samples were then preserved until digestion.

Table 1. Locations of the sampling stations along the Shitalakhya river basin at Polash-Ghorashal region, Bangladesh.

\begin{tabular}{|c|c|c|c|}
\hline Region & $\begin{array}{c}\text { Sam } \\
\text { pling } \\
\text { ID }\end{array}$ & $\begin{array}{c}\text { Upstream/ } \\
\text { Downstream }\end{array}$ & $\begin{array}{c}\text { Description of Location } \\
\text { (Distance from Point source of } \\
\text { UFF) }\end{array}$ \\
\hline \multirow{8}{*}{ 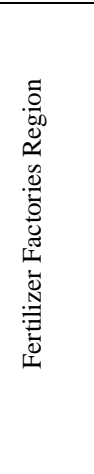 } & FS1 & upstream & $100 \mathrm{~m}$ \\
\hline & FS2 & downstream & $\begin{array}{l}\text { 3-5 m (Point source of } \\
\text { Ghorashal FF) }\end{array}$ \\
\hline & FS3 & downstream & $400 \mathrm{~m}$ \\
\hline & FS4 & downstream & $800 \mathrm{~m}$ (Point source of PUFF) \\
\hline & FS5 & downstream & $\begin{array}{l}150 \mathrm{~m} \text { opposite from P.S. of } \\
\text { UFF }\end{array}$ \\
\hline & FS6 & downstream & $500 \mathrm{~m}$ opposite from UFF \\
\hline & FS7 & downstream & $1 \mathrm{~km}$ opposite from UFF \\
\hline & CS1 & downstream & $10 \mathrm{~km}$ (Seven ring cement area) \\
\hline \multirow{3}{*}{  } & $\mathrm{CS} 2$ & downstream & $11 \mathrm{~km}$ (Seven ring cement area) \\
\hline & CS3 & downstream & $14 \mathrm{~km}$ (Seven ring cement area) \\
\hline & PS1 & downstream & $12 \mathrm{~km}$ (Paper mill area) \\
\hline \multirow{2}{*}{ 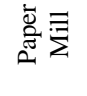 } & PS2 & downstream & 13 km (Paper mill area) \\
\hline & PS3 & downstream & 14 km (Paper mill area) \\
\hline
\end{tabular}

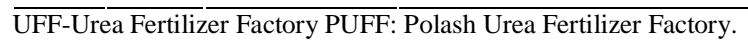

\section{Digestion of Sediment Samples}

The ASTM digestion protocol was applied to digest the sediment samples [5]. Exactly $1.0 \mathrm{~g}$ of the finely powdered sample was added to $12 \mathrm{~mL} \mathrm{HNO}_{3}$ that was already kept in a $250 \mathrm{~mL}$ tetrafluoroethylene (TFE) made beaker (tall) with cover. The beaker was then placed on a hot plate $\left(200{ }^{\circ} \mathrm{C}\right)$ for about $30 \mathrm{~min}$ followed by the addition of $12 \mathrm{~mL} \mathrm{HF}$ (sp gr 1.19) and $4 \mathrm{~mL} \mathrm{HClO}_{4}$. The solution was heated until no white fume was observed. Few drops of concentrated $\mathrm{HNO}_{3}$ were added to confirm the complete digestion. The same ASTM digestion protocol was applied for the analysis of reagent blank $\left(\mathrm{B}_{\text {reg }}\right)$ and certified reference materials (CRM) [5]. Samples, $B_{\text {reg }}$ and CRM were analyzed in triplicate sets.

After completion of digestion, the samples were cooled and then filtered through Whatman No. 42 filter paper and finally diluted to $100 \mathrm{~mL}$ with deionized water. All the samples were preserved in a refrigerator at 4-6 ${ }^{\circ} \mathrm{C}$ for chemical analysis. All the reagents were purchased from Merck (Germany) and $\mathrm{BDH}, \mathrm{UAE}) \mathrm{ARISTAR}$ grade.

\section{Chemical Analysis}

Concentrations of the heavy metals in the sediments were determined using a Flame Atomic Absorption Spectrophotometer (Model No. 240 AA, Agilent, Australia) where air-acetylene flame was used. The accuracy of the results obtained for the sediments was validated against the Certified Reference Materials (CRM). The CRM was verified against SRM 3100 series developed by NIST. The certificate value for the CRM was calculated to obtain the uncertainty (relative standard deviation, RSD) of the applied method. The uncertainty (RSD) was found to be $\leq 5 \%$. 


\section{Analytical Validation}

A series of standard solutions for each metal ion was prepared through dilution of the respective supplied standard solution to construct the analytical calibration curve. Linearity was evaluated by calculating four points linear plot with six replicate measurements for each point, based on the linear regression and squared correlation coefficient, $R^{2}$ ( $\left.\geq 0.995\right)$. The linearity range for the heavy metals examined was as follows: 0 - $4 \mathrm{mg} / \mathrm{L}$ for $\mathrm{Cr}$, Ni and $\mathrm{Zn} ; 0$ - $20 \mathrm{mg} / \mathrm{L}$ for $\mathrm{Mn}$ and $0-10 \mathrm{mg} / \mathrm{L}$ for $\mathrm{Cu}$.

\section{Sediment Pollution Assessment Geo-accumulation index of sediment}

The degree of pollution in the aquatic sediments can be assessed by calculating the geo-accumulation indices $\left(I_{\text {geo }}\right)$. The indices were calculated by background geochemical values for shale using the following equation [6].

$$
\text { Igeo }=\log \left[\frac{\mathrm{C}_{\mathrm{n}}}{1.5 \times \mathrm{B}_{\mathrm{n}}}\right]
$$

Here, $C_{\mathrm{n}}$ indicates the measured concentrations for $\mathrm{n}^{\text {th }}$ heavy metals and $B_{n}$ is the metal's concentration in average shale value [7].

The background values were corrected by introducing the factor 1.5 in eq. (1) to minimize the lithogenic effect in the background values. On the basis of the geoaccumulation indices $\left(I_{\mathrm{geo}}\right)$, the study area can be categorized into seven classes from the contamination point of view: uncontaminated $\left(I_{\text {geo }} \leq 0\right)$, uncontaminated to moderately contaminated $\quad\left(0<I_{\text {geo }}<1\right), \quad$ moderately contaminated $\left(1<I_{\text {geo }}<2\right)$, moderately to strongly contaminated $\left(2<I_{\text {geo }}<3\right)$, strongly contaminated $\left(3<I_{\mathrm{geo}}<4\right), \quad$ strongly to extremely strongly contaminated $\left(4<I_{\text {geo }}<5\right)$ and extremely contaminated $\left(I_{\text {geo }}>5\right)$.

Contamination factor $\left(C_{\mathrm{f}}^{\mathrm{i}}\right)$ and degree of contamination $\left(C_{d}\right)$ for the heavy metal examined

Hakanson developed statistical models to calculate the contamination factor $\left(C_{\mathrm{f}}\right)$ and degree of contamination $\left(C_{\mathrm{d}}\right)$ for the heavy metals of interest [8]. The statistical models in calculating the contamination factor $\left(C_{\mathrm{f}}\right)$ and degree of contamination $\left(C_{\mathrm{d}}\right)$ can be expressed by eq. (2) and (3), respectively. According to eq. (2), contamination factor $\left(C_{\mathrm{f}}\right)$ is the ratio of the estimated concentration of the metals of interest in the sediments and the background value for the same metal while the contamination factor $\left(C_{\mathrm{d}}\right)$ is the sum of all the $C_{\mathrm{f}}$ values as shown in eq. (3) [8]. These two parameters are needed for assessing the ecological risk by the relevant metals present in the sediments. The equations for calculation of the contamination factor $\left(C_{\mathrm{f}}^{\mathrm{i}}\right)$ and the degree of contamination $\left(C_{\mathrm{d}}\right)$ are as follows:

$$
\begin{aligned}
& C_{f}^{i}=\frac{C_{o}^{i}}{C_{n}^{i}} \\
& C_{d}^{i}=\sum_{i=1}^{n} C_{f}^{i}
\end{aligned}
$$

Where, $\left(\mathrm{C}_{\mathrm{o}}^{\mathrm{i}}\right)$ stands for the concentration of the heavy metals in the collected sediments and $\left(\mathrm{C}_{\mathrm{n}}^{\mathrm{i}}\right)$ is the background value for shale $(\mathrm{mg} / \mathrm{kg})$. The background values were taken from previously reported by Hakansonbecause of the unavailability of standard data in this study [8]. The background values $\left(C_{\mathrm{n}}\right)$ for $\mathrm{Cr}, \mathrm{Mn}$, $\mathrm{Ni}, \mathrm{Cu}$ and $\mathrm{Zn}$ were 90, 850, 68, 50 and 175 $\mathrm{mg} / \mathrm{kg}$, respectively. Hakanson classified the sediment contamination into four groups on the basis of the values of the contamination factor and degree of contamination as shown in Table 2 [8]. 
Table 2. Contamination factor $\left(C_{f}^{i}\right)$, degree of contamination $\left(C_{\mathrm{d}}\right)$, degree of potential ecological risk $\left(E_{r^{i}}^{i}\right)$ and degree of total potential ecological risk $\left(R_{\mathrm{I}}\right)$.

\begin{tabular}{|c|c|c|c|c|c|c|}
\hline$C_{f}^{i}$ & $C_{\mathrm{d}}$ & $\begin{array}{l}\text { Contamination } \\
\text { factor and degree } \\
\text { of contamination } \\
\text { of heavy metal }(i)\end{array}$ & $E_{r}^{i}$ & $\begin{array}{l}\text { Degree of potential } \\
\text { ecological risk of } \\
\text { heavy metal }(i)\end{array}$ & $R_{\mathrm{I}}$ & $\begin{array}{l}\text { Degree of total } \\
\text { potential } \\
\text { ecological risk of } \\
\text { heavy metals }\end{array}$ \\
\hline$C_{f<1}^{i}$ & $C_{d}^{t}<8$ & Light & $E_{r}^{i}<40$ & Light & $R_{\mathrm{I}}<150$ & Light \\
\hline $1 \leq C_{f}^{i}<3$ & $8 \leq C_{d}^{i}<16$ & Moderate & $40 \leqslant E_{r}^{i}<80$ & Moderate & $150 \leq R_{\mathrm{I}}<300$ & Moderate \\
\hline $3 \leq C_{f}^{i}<6$ & $16 \leq C_{d}^{i}<32$ & Heavy & $80 \leq E^{i}<160$ & Heavy & $300 \leq R_{\mathrm{I}}<600$ & Heavy \\
\hline$C_{f}^{i} \geq 6$ & $C_{d}^{i}<32$ & Very heavy & $\begin{array}{l}160 \leq E_{r}^{i}<320 \\
E_{r} \geq 320\end{array}$ & $\begin{array}{l}\text { Very heavy } \\
\text { Extremely }\end{array}$ & $R_{\mathrm{I}} \geq 600$ & Very heavy \\
\hline
\end{tabular}

\section{Pollution load index (PLI)}

A modified statistical parameter known as pollution load index (PLI) proposed by Tomlinson et al., that has widely been used to quantify a component in the contaminated environment [9]. The PLI can be defined as the $n$th root of $n$ number of multiple products of the contamination factor $\left(C_{\mathrm{f}}\right)$. The PLI values can be calculated by the following eq. (4).

$\mathrm{PLI}=\left[(\mathrm{Cf}]_{1}^{*} \mathrm{Cf}_{2}^{*} \mathrm{Cf}_{3}^{*} \ldots \mathrm{Cf}_{\mathrm{n}}^{*}\right)^{\frac{1}{\mathrm{n}}}$

The calculated PLI values are necessary to predict the metal pollution level in sediments. On the basis of PLI values, pollution can be classified into two groups: PLI $>1$ indicates pollution while that less than 1 designates no pollution.

\section{Ecological risk assessment}

Hakanson introduced an additional statistical parameter known as ecological risk index $\left(R_{1}\right)$ to assess the ecological risk for polluted aquatic environments [8]. The ecological risk index $\left(R_{1}\right)$ was calculated by using the monomial potential ecological risk factor $\left(E_{\mathrm{r}}\right)$ and toxic response factor $\left(T_{\mathrm{r}}\right)$ for each heavy metal. It is possible to predict the degree of metal pollution in the sediment by knowing the value of the $R_{1}$. The $R_{1}$ index was calculated by using the following eq. (5) and (6):

$E_{r}^{i}=T_{r}^{i} C_{f}^{i}$
$R_{1} \sum E_{r}^{i}$

As mentioned, $E_{r^{i}}^{i}$ stands for monomial potential ecological risk factor and $T_{r}^{i}$ is the toxic response factor for each heavy metal. The toxic response factors were taken from the previous studies and values for $\mathrm{Cr}, \mathrm{Mn}, \mathrm{Ni}$, $\mathrm{Cu}, \mathrm{Zn}, \mathrm{As}, \mathrm{Cd}, \mathrm{Hg}$ and $\mathrm{Pb}$ are 2, 1, 2, 5, 1, 10, 30,30 and 5 , respectively $[8,10]$. In Table 2 , the values of the degree of ecological risk potential and degree of total ecological risk potential for the metals examined are listed.

\section{Results and Discussion \\ Seasonal and Site-to-Site (Spatial) Variation of Heavy Metals in the Sediments}

The concentrations of the heavy metals i.e., $\mathrm{Cr}, \mathrm{Mn}, \mathrm{Ni}, \mathrm{Cu}$ and $\mathrm{Zn}$ in the surface sediments were measured using AAS through acid digestion. Thirteen sampling sites were chosen to collect the sediment samples from the river Shitalakhya in the dry (January, 2012), pre-monsoon (April, 2012) and postmonsoon (October, 2012) (Table 1 and Fig. 1). The concentrations for seasonal and site dependent (spatial variation) variation of the heavy metals are tabulated in Table 3. As seen from Table 3 , the mean concentrations for the dry and pre-monsoon were slightly higher than that of the post-monsoon. The results show that only Mn was found with the highest concentration among the metals examined, however, the lowest concentration was for $\mathrm{Cr}$ with respect to spatial and seasonal variation. 
Table 3. Concentrations $(\mathrm{mg} / \mathrm{kg})$ of the heavy metals in sediments of the Shitalakhya river in the dry season (January, 2012), premonsoon (April, 2012) and post-monsoon (October, 2012).

\begin{tabular}{|c|c|c|c|c|c|c|c|c|c|c|c|c|c|c|c|}
\hline $\begin{array}{l}\text { Heavy } \\
\text { Metals }\end{array}$ & $\begin{array}{l}\text { Sampling } \\
\text { Sites }\end{array}$ & FS1 & FS2 & FS3 & FS4 & FS5 & FS6 & FS7 & CS1 & CS2 & PS1 & PS2 & PS3 & C S3 & $\begin{array}{l}\text { Mean } \\
\pm \text { SD }\end{array}$ \\
\hline \multirow{3}{*}{$\mathrm{Cr}$} & Dry Season & 29.58 & 23.40 & 27.63 & 24.78 & 13.48 & 19.27 & 18.69 & 22.64 & 34.73 & 24.19 & 17.32 & 21.21 & 13.84 & $\begin{array}{l}22.37 \\
\pm 6.09\end{array}$ \\
\hline & $\begin{array}{l}\text { Pre- } \\
\text { monsoon }\end{array}$ & 21.31 & 29.72 & 32.06 & 38.09 & 35.22 & 39.81 & 34.96 & 33.33 & 26.80 & 30.95 & 24.23 & 33.08 & 30.96 & $\begin{array}{l}31.58 \\
\pm 5.22\end{array}$ \\
\hline & $\begin{array}{l}\text { Post- } \\
\text { monsoon }\end{array}$ & 16.93 & 29.31 & 21.69 & 23.45 & 29.63 & 16.83 & 16.53 & 11.72 & 13.07 & 13.08 & 12.56 & 11.00 & 19.36 & $\begin{array}{r}18.09 \\
\pm 6.32\end{array}$ \\
\hline \multirow{3}{*}{ Mn } & Dry Season & 729.90 & 723.65 & 842.64 & 464.40 & 773.85 & 362.43 & 559.04 & 682.57 & 451.95 & 788.48 & 396.82 & 538.44 & 649.56 & $\begin{array}{r}612.59 \\
\pm 160.08\end{array}$ \\
\hline & $\begin{array}{l}\text { Pre- } \\
\text { monsoon }\end{array}$ & 744.21 & 597.23 & 628.26 & 674.16 & 588.86 & 666.16 & 542.1 & 588.89 & 533.17 & 336.21 & 396.87 & 490.02 & 620.14 & $\begin{array}{c}569.71 \\
\pm 112.16\end{array}$ \\
\hline & $\begin{array}{l}\text { Post- } \\
\text { monsoon }\end{array}$ & 624.56 & 669.43 & 746.17 & 652.29 & 432.30 & 582.70 & 574.73 & 425.57 & 697.70 & 497.23 & 353.12 & 538.76 & 576.65 & $\begin{array}{c}567.02 \\
\pm 115.55\end{array}$ \\
\hline \multirow{3}{*}{$\mathrm{Ni}$} & Dry season & 62.03 & 55.94 & 65.21 & 61.50 & 41.02 & 48.42 & 53.83 & 69.11 & 62.21 & 59.01 & 45.45 & 51.32 & 28.38 & $\begin{array}{c}54.11 \\
\pm 11.21\end{array}$ \\
\hline & $\begin{array}{l}\text { Pre- } \\
\text { monsoon }\end{array}$ & 55.11 & 65.73 & 59.0 & 64.55 & 59.64 & 67.12 & 56.26 & 56.45 & 56.28 & 36.78 & 54.66 & 65.50 & 61.48 & $\begin{array}{l}58.35 \\
\pm 7.82\end{array}$ \\
\hline & $\begin{array}{l}\text { Post- } \\
\text { monsoon }\end{array}$ & 37.60 & 51.94 & 58.91 & 50.89 & 64.79 & 51.10 & 52.40 & 46.99 & 48.53 & 51.32 & 44.87 & 47.59 & 54.69 & $\begin{array}{r}50.89 \\
\pm 6.58\end{array}$ \\
\hline \multirow{3}{*}{$\mathrm{Cu}$} & Dry season & 57.18 & 73.44 & 54.97 & 54.33 & 34.38 & 41.13 & 43.90 & 50.21 & 44.50 & 50.47 & 50.8 & 46.02 & 53.37 & $\begin{array}{l}50.36 \\
\pm 9.40\end{array}$ \\
\hline & $\begin{array}{l}\text { Pre- } \\
\text { monsoon }\end{array}$ & 44.55 & 99.12 & 49.70 & 56.15 & 53.24 & 55.15 & 41.65 & 43.22 & 42.50 & 21.20 & 41.99 & 54.53 & 46.12 & $\begin{array}{c}49.93 \\
\pm 17.36\end{array}$ \\
\hline & $\begin{array}{l}\text { Post- } \\
\text { monsoon }\end{array}$ & 36.12 & 39.39 & 45.60 & 42.95 & 40.50 & 47.71 & 36.61 & 36.76 & 38.83 & 36.50 & 30.78 & 43.34 & 41.72 & $\begin{array}{l}39.75 \\
\pm 4.56\end{array}$ \\
\hline \multirow{3}{*}{$\mathrm{Zn}$} & Dry Season & 93.17 & 297.57 & 99.18 & 120.84 & 55.98 & 83.49 & 79.33 & 124.42 & 97.52 & 92.53 & 72.06 & 92.25 & 38.74 & $\begin{array}{r}103.62 \\
\pm 62.74\end{array}$ \\
\hline & $\begin{array}{l}\text { Pre- } \\
\text { monsoon }\end{array}$ & 55.43 & 423.28 & 100.7 & 98.11 & 96.83 & 104.3 & 87.57 & 74.58 & 82.77 & 37.17 & 88.01 & 96.14 & 96.52 & $\begin{array}{r}110.88 \\
\pm 95.83\end{array}$ \\
\hline & $\begin{array}{l}\text { Post- } \\
\text { monsoon }\end{array}$ & 50.5 & 44.32 & 62.91 & 60.53 & 76.47 & 67.62 & 55.11 & 48.61 & 30.59 & 48.95 & 56.32 & 58.37 & 57.58 & $\begin{array}{r}55.22 \\
\pm 11.33 \\
\end{array}$ \\
\hline
\end{tabular}

The present results were compared with the previous results found in Bangladesh and abroad (Table 4). Results show that the mean concentrations of $\mathrm{Cr}$ were $22.37 \pm 6.09$, $31.58 \pm 5.22$ and $18.09 \pm 6.32 \mathrm{mg} / \mathrm{kg}$ in the dry, pre-monsoon and post-monsoon, respectively (Table 3). Chromium was found with its highest concentration at site-FS6 followed by FS4 $>$ FS5 $>$ FS7 $>$ CS2 $>$ PS3 $>$ FS3 in the pre-monsoon (Table 3). However, in the dry season, sites-CS2 and FS1 were contaminated with the highest concentration of $\mathrm{Cr}$ (Table 3). It has been reported that concentration of $\mathrm{Cr}$ was $74.82 \mathrm{mg} / \mathrm{kg}$ in the sediment of the river Shitalakhya [11] while the present study showed only $24.01 \pm 6.89$ $\mathrm{mg} / \mathrm{kg}$ of that is three times lower than the previous result (Table 4). Both the results are logical. This is because the present study area is upstream of the river which is known as one of the less heavy metal polluted zones of the river whereas the study area by Islam et al., is the downstream of the river that is well-known polluted zone [11].

In our previous study, we found a moderate concentration of $\mathrm{Cr}$ in the sediments of the river Buriganga $(41.45 \pm 15.88 \mathrm{mg} / \mathrm{kg}$, February $2015 ; 39.70 \pm 18.84 \mathrm{mg} / \mathrm{kg}$, August 2016) [12]. However, a very high concentration of $\mathrm{Cr}(709.40 \mathrm{mg} / \mathrm{kg})$ was reported by Mohiuddin et al., in the same river sediment (Table 4) [13]. The river Buriganga has been regarded as the most polluted river with $\mathrm{Cr}$ in Bangladesh. This is because of the direct discharge of tanning wastewater from the tanning factories that were situated on the bank of the river Buriganga. In late 2017, the tanning factories have already been relocated to another industrial zone, Savar, Dhaka, Bangladesh in order to save the Buriganga river as well as city dwellers of Dhaka, one of 
the largest metropolitan cities in Asia with about 20 million populations. In another study related to the sediment of the river Buriganga, they also found a high concentration of $\mathrm{Cr}$ $(174.53 \mathrm{mg} / \mathrm{kg})$ (Table 4) [14]. High concentration of $\mathrm{Cr}(101.20 \mathrm{mg} / \mathrm{kg})$ has also been reported by Saha and Hossain [15] and Majumder et al., (Table 4) [16]. The river Meghna is treated as one of the less polluted rivers in Bangladesh and the concentration of $\mathrm{Cr}$ was found to be $31.74 \mathrm{mg} / \mathrm{kg}$ [17].

The peripheral rivers such as Turag, Bangshi of the Dhaka city have also been contaminated through the direct discharge of industrial wastewater from different types of industries. Accordingly, some research groups have already taken initiatives to analyze sediment, water and fish samples not only for heavy metals but also for organic pollutants $[10,18,19]$. Concentrations of $\mathrm{Cr}$ in the sediments collected from the Turag and Bangshi rivers were found to be 43.02 and $98.10 \mathrm{mg} / \mathrm{kg}$, respectively (Table 4) [10,18]. Khan et al., found the concentration of $\mathrm{Cr}$ in the sediment collected from Turag river within a range from 25.2 to $123.0 \mathrm{mg} / \mathrm{kg}$ [19]. There are many different types of industries on the banks of the Turag and Bangshi rivers. The direct discharges of the wastewater from these industries have heavily polluted the river water with many heavy metals for a long time [20]. The lowest concentration of $\mathrm{Cr}$ was found adjacent to the paper mills (sites-PS2PS3). This is because paper mills generally use different types of organic chemicals, for example, alkenyl succinic anhydrides (ASA), alkyl ketene dimers (AKD), carboxy methyl cellulose (CMC) etc. in various purposes such as sizing, pulping, deinking, stickies control, cleaning, etc. So, there is little chance for heavy metal pollution from the wastewater of the paper mills.

The present results have been compared to those reported by other groups abroad. The concentration of $\mathrm{Cr}$ was found within a range from 41.69 to $128.3 \mathrm{mg} / \mathrm{kg}$ in the sediments of the Yellow River in China [21], however, that was from 4.05 to 430.61 $\mathrm{mg} / \mathrm{kg}$ in the sediments collected from the BT Drainage river, China (Table 4) [22]. In the sediment of the river Cheliff, Algeria, the concentration of $\mathrm{Cr}$ was found to be 191.0 $\mathrm{mg} / \mathrm{kg}$ (Table 4) [23]. Moreover, the concentration of $\mathrm{Cr}$ in the sediment collected from the Gediz river was found to be within a range from 170 to $220 \mathrm{mg} / \mathrm{kg}$ (Table 4) [24]. However, the concentration of $\mathrm{Cr}$ in the sediment of the Ganges was quite low, ranging from 4.28 to $8.40 \mathrm{mg} / \mathrm{kg}$ (Table 4) [25]. Among the mentioned rivers in Table 4, the sediment of the Ganges was unexpectedly less contaminated with $\mathrm{Cr}$.

According to the Ontario Ministry of Environment and Energy, Canada, the severe effect level (SEL) for $\mathrm{Cr}$ is $110 \mathrm{mg} / \mathrm{kg}$ while the mean concentrations for that were only $22.37 \pm 6.09,31.58 \pm 5.22$ and $18.09 \pm 6.32$ $\mathrm{mg} / \mathrm{kg}$ in the dry, pre-monsoon and postmonsoon, respectively (Table 4) [26]. Moreover, the mean concentrations of $\mathrm{Cr}$ were also lower than the threshold effect level (TEL) $37.30 \mathrm{mg} / \mathrm{kg}$ except for site-FS4, where Cr was found to be slightly elevated (38.09 $\mathrm{mg} / \mathrm{kg}$ ) compared to the TEL level (Tables 3 and 4). Concentrations of $\mathrm{Cr}$ in the sediments collected during the pre-monsoon were higher than the toxicity reference value (TRV) 26.00 $\mathrm{mg} / \mathrm{kg}$ at all the sites except for sites-FS2 $(21.31 \mathrm{mg} / \mathrm{kg})$ and PS2 (24.23 $\mathrm{mg} / \mathrm{kg})$, however, that in the dry season and postmonsoon were lower than the TR value at all the sites except for sites-FS2 (29.58) and FS3 (27.63) (dry season) and sites-FS2 (29.31 $\mathrm{mg} / \mathrm{kg}$ ) and FS5 (29.63 $\mathrm{mg} / \mathrm{kg})$ (postmonsoon) (Tables 3 and 4) [27, 28].

The mean concentrations of $\mathrm{Mn}$ in the dry, pre-monsoon and post-monsoon were $612.59 \pm 160.08,569.71 \pm 112.16$ and 567.02 $\pm 115.55 \mathrm{mg} / \mathrm{kg}$ in the sediments, respectively 
(Table 3). Site-FS3 was contaminated with its highest concentration $(842.64 \mathrm{mg} / \mathrm{kg})$ followed by PS1 > FS5 > FS1 in the dry season (Table 3). The site-FS3 is $400 \mathrm{~m}$ downstream from the point source, however, site-FS2 is $3-5 \mathrm{~m}$ downstream from the point source of the urea fertilizer factory. Site-FS5 is opposite of the urea fertilizer factory at 150 $\mathrm{m}$ downstream from the point source. Site-PS2 is close to the paper mill and $12 \mathrm{~km}$ downstream from the point source. The high concentration of Mn at sites FS5 and FS2 is implausible (Tables 1 and 3). The possible reason for the high concentration of $\mathrm{Mn}$ at these two sites may be due to spreading the contaminated water by running many engine boats in the river. In the pre-monsoon, the highest concentration was at site-FS2 (744.21 $\mathrm{mg} / \mathrm{kg}$ ) followed by FS4>FS6 $>$ FS3 (Table 3). The high concentration of $\mathrm{Mn}$ at these sites is logical because these sites are downstream from the point source. The high concentrations of $\mathrm{Mn}$ were also found in the sediments collected from the Bangshi [10] and Meghna [17] rivers. The concentration of Mn in the river sediments for Bangshi river was found to be $483.44 \mathrm{mg} / \mathrm{kg}$ [10], while that for Meghna river was $442.60 \mathrm{mg} / \mathrm{kg}$ [17]. In our previous study, we found relatively low concentrations of $\mathrm{Mn}$ in the sediments collected from the river Buriganga and that was $37.58 \pm 3.13$ and $39.06 \pm 2.72 \mathrm{mg} / \mathrm{kg}$ during the monsoon and winter, respectively (Table 4) [12]. The lowest concentration of $\mathrm{Mn}$ was found adjacent to the paper mills (sites-PS2-PS3) (Table 3). This is because paper mills generally use different types of organic chemicals, for example, alkenyl succinic anhydrides (ASA), alkyl ketene dimers (AKD), carboxymethyl cellulose (CMC), etc. in various purposes such as sizing, pulping, deinking, stickies control, cleaning, etc. So, there is little chance for heavy metal pollution from the wastewater of paper mills. Liu et al., reported a very high concentration of $\mathrm{Mn}$ in the sediment of the
Yellow River, China and that was ranging from 773.2 to $1459.7 \mathrm{mg} / \mathrm{kg}$ (Table 4) [21]. A high concentration of Mn was also reported in the Gediz river sediment in Turkey that was within a range from 380 to $420 \mathrm{mg} / \mathrm{kg}$ (Table 4) [24]. The present results were not compared with the TEL, TRV and SEL values because of their unavailability in the literature (Table 4).

In the case of $\mathrm{Ni}$, the mean concentrations of $\mathrm{Ni}$ in the sediments were $54.11 \pm 11.21,58.35 \pm 7.82$ and $50.89 \pm 6.58$ $\mathrm{mg} / \mathrm{kg}$ during the dry, pre-monsoon and postmonsoon, respectively (Table 3). Among the sampling sites, site-CS1 (near to cement factory) was contaminated with the maximum concentration of $\mathrm{Ni}(69.11 \mathrm{mg} / \mathrm{kg})$ followed by FS3 $>$ CS2 $>$ FS2 $>$ FS4 in the dry season while that was the highest $(67.12 \mathrm{mg} / \mathrm{kg})$ at site-FS6 followed by FS2 $>$ PS $3>$ FS $4>$ CS3 in the pre-monsoon (Table 3 ). In our previous study, we found only $6.39 \pm 0.96$ and $7.14 \pm$ $1.11 \mathrm{mg} / \mathrm{kg}$ of $\mathrm{Ni}$ in the sediments collected from the river Buriganga in the monsoon and winter, respectively (Table 4) [12]. The present concentration of $\mathrm{Ni}$ is about 8 times higher than that reported by Nargis et al., [12] though the Buriganga river has been heavily contaminated with heavy metals because of the direct discharge of the industrial wastewater into the river water for a long time [20]. The high concentration of $\mathrm{Ni}$ in the Shitalakhya river's sediments is reasonable. This is because of the use of $\mathrm{Ni}$ as a catalyst in the ammonia-urea plant in the study area. Nickel has been leached out from the dumped catalysts that kept inside the ammonia-urea factory, thereby resulting in contamination of $\mathrm{Ni}$ with the river water and/or sediment through rain washed water. In the earlier studies, concentrations of $\mathrm{Ni}$ were found to be $137.35 \mathrm{mg} / \mathrm{kg}$ [13] and $200.45 \mathrm{mg} / \mathrm{kg}$ [14] in the sediment of the river Buriganga (Table 4). 
Table 4. Comparison of concentrations of the heavy metals $(\mathrm{mg} / \mathrm{kg})$ in sediments of the Shitalakhya river with other rivers of Bangladesh and abroad.

\begin{tabular}{|c|c|c|c|c|c|c|}
\hline Sample area & $\mathrm{Cr}$ & Mn & $\mathrm{Ni}$ & $\mathbf{C u}$ & $\mathbf{Z n}$ & References \\
\hline \multicolumn{7}{|l|}{ Shitalakhya River (*BD) } \\
\hline Dry & 22.37 & 612.59 & 54.11 & 50.36 & 103.62 & \\
\hline Pre-monsoon & 31.58 & 569.71 & 58.35 & 49.93 & 22.37 & Present study \\
\hline Post-monsoon & 18.09 & 567.02 & 50.89 & 39.75 & 31.58 & \\
\hline Turag River & 25.2 to 123.0 & $115-1888$ & -- & -- & -- & Khan et al. [19] \\
\hline \multicolumn{7}{|l|}{ Buriganga River (BD) } \\
\hline Monsoon & 39.70 & 37.58 & 6.39 & 14.07 & 36.73 & \\
\hline Winter & 41.45 & 39.06 & 7.14 & 15.93 & 40.71 & Nargis et al. [12] \\
\hline Buriganga River (BD) & 101.20 & ${ }^{* * *} \mathrm{NA}$ & NA & 49.80 & 50.70 & Majumdar et al. [16] \\
\hline Buriganga River (BD) & 101.20 & NA & NA & 184.40 & 502.30 & Saha and Hossain [15] \\
\hline Buriganga River (BD) & 709.41 & NA & 137.35 & 224.55 & 958.15 & Mohiuddin et al. [13] \\
\hline Buriganga River (BD) & 174.53 & NA & 200.45 & 30.35 & NA & Ahmad et al. [14] \\
\hline Shitalakhya River (BD) & 74.82 & NA & NA & 143.69 & 200.59 & Islam et al. [11] \\
\hline Turag River (BD) & 43.02 & NA & NA & 50.40 & 139.48 & Banu et al. [18] \\
\hline Bangshi River (BD) & 98.10 & 483.44 & 25.67 & 31.01 & 117.17 & Rahman et al. [10] \\
\hline Meghna River (BD) & 31.74 & 442.60 & 76.12 & NA & 79.02 & Hasan et al. [17] \\
\hline BT Drainage River (China) & $4.05-430.61$ & NA & NA & $26.71-2006.67$ & $164.20-2731.12$ & Wang et al. [22] \\
\hline Yellow River (China) & $41.69-128.3$ & $773.2-1459.7$ & NA & $29.72-102.22$ & $89.80-201.88$ & Liu et al. [21] \\
\hline River Ganges (India) & $1.80-6.40$ & NA & NA & $0.98-4.42$ & $10.48-20.40$ & Gupta et al. [25] \\
\hline Gediz River (Turkey) & $170-220$ & $380-420$ & 101.13 & 108.15 & $40-180$ & Akcay et al. [24] \\
\hline Shur River (Iran) & NA & NA & NA & 135 & 250 & Karbassi et al. [29] \\
\hline Cheliff River (Algeria) & 191 & NA & NA & 102.00 & 288 & Belhadj et al. [23] \\
\hline TEL (Threshold Effect Level) & 37.3 & NA & 18 & 35.7 & 123 & Macdonald et al. [28] \\
\hline $\begin{array}{l}\text { TRV (Toxicity Reference } \\
\text { Value) }\end{array}$ & 26 & - & 16 & 16 & 110 & US EPA [27] \\
\hline SEL (Severe Effect Level) & 110 & NA & 75 & 110 & 820 & Persuad et al. [26] \\
\hline
\end{tabular}

${ }^{*}$ BD stands for Bangladesh

*** NA stands for not analyzed

Proper authorities of the People's Republic of Bangladesh have taken an attempt to reclaim the Buriganga river as it became less contaminated through dredging the river during 2014-2015. The sampling by Nargis et al., [12] was done during August 2015 (monsoon) and February 2016 (winter) that was after the dredging. However, the results reported by Mohiuddin et al., [13] and Ahmed et al., [14] were before dredging the Buriganga river. The concentration of $\mathrm{Ni}$ was only $25.67 \mathrm{mg} / \mathrm{kg}$ in the sediment of the Bangshi river that is unlikely [10]. This is because the Bangshi river is also known as 
one of the polluted rivers in Bangladesh. The river Meghna is known as one of the less polluted rivers in Bangladesh, however, the concentration of $\mathrm{Ni}$ was found to be 76.12 $\mathrm{mg} / \mathrm{kg}$ in the sediment samples (Table 4) [17]. A high concentration of $\mathrm{Ni}(101.13 \mathrm{mg} / \mathrm{kg})$ was found in the sediment of the river Gediz, Turkey, that reported by Akcay et al., [24]. Although the TEL $(18 \mathrm{mg} / \mathrm{kg})$ and TRV (16 $\mathrm{mg} / \mathrm{kg}$ ) values were below than the present concentrations of $\mathrm{Ni}$ (Dry: $54.11 \pm 11.21$ $\mathrm{mg} / \mathrm{kg}$; pre-monsoon: $58.35 \pm 7.82 \mathrm{mg} / \mathrm{kg}$; post-monsoon: $50.89 \pm 6.58 \mathrm{mg} / \mathrm{kg}$ ) but the SEL value $(110 \mathrm{mg} / \mathrm{kg})$ was much higher than that observed in this study. The results suggest that though the study area was noncontaminated by $\mathrm{Ni}$ on the basis of TEL and TRV values, moderately contaminated with respect to SEL.

Concentrations of $\mathrm{Cu}$ were also estimated through a collection of the river sediment samples in the three seasons. In the dry, pre-monsoon and post-monsoon, the mean concentrations of $\mathrm{Cu}$ were found to be $50.36 \pm 9.40,49.93 \pm 17.36$ and $39.75 \pm 4.56$ $\mathrm{mg} / \mathrm{kg}$, respectively (Table 3). However, a high concentration of $\mathrm{Cu}, 143.69 \mathrm{mg} / \mathrm{kg}$, in the sediment of the river Shitalakhya has been reported by Islam et al., [11]. The two study areas were different zones of the Shitalakhya river, as described in the preceding section. The present study area was upstream, while the study area by Islam et al., was downstream that has been considered as the highly contaminated zone of the Shitalakhya river [11].

On the other hand, Nargis et al., reported low concentrations of $\mathrm{Cu}$ in the sediments of the river Buriganga, known as the most polluted river in Bangladesh [12]. Concentrations of $\mathrm{Cu}$ in the winter (February 2016) and monsoon (August 2015) were 14.07 \pm 15.93 and $15.93 \pm 18.38 \mathrm{mg} / \mathrm{kg}$, respectively (Table 4) [12]. A reclamation project of the river bed of the river Buriganga was executed during 2014-2015 that is the reason to find the low concentrations of $\mathrm{Cu}$ in the river sediments. In the earlier studies, concentrations of $\mathrm{Cu}$ in the sediments of the river Buriganga were found to be $30.35 \mathrm{mg} / \mathrm{kg}$ [14] and $224.55 \mathrm{mg} / \mathrm{kg}$ (Table 4) [13]. A high concentration of $\mathrm{Cu}(184.40 \mathrm{mg} / \mathrm{kg})$ has also been reported by Saha and Hossain in the river Buriganga [15]. However, Majumder et al., found only $49.80 \mathrm{mg} / \mathrm{kg}$ of $\mathrm{Cu}$ in the same river sediment (Table 4) [16]. About 50.40 $\mathrm{mg} / \mathrm{kg}$ of $\mathrm{Cu}$ was found in the sediment of Turag river [10], while that was about 31.01 $\mathrm{mg} / \mathrm{kg}$ in the Bangshi river (Table 4) [18].

A very low concentration of $\mathrm{Cu}$ ranging from 0.98 to $4.42 \mathrm{mg} / \mathrm{kg}$ was found in the Ganges' sediment (Table 4) [25]. However, in the sediment of the BT Drainage river, China, the lowest concentration of $\mathrm{Cu}$ was $26.71 \mathrm{mg} / \mathrm{kg}$ while the maximum of that was $2006.67 \mathrm{mg} / \mathrm{kg}$ [22]. Liu et al., also analyzed $\mathrm{Cu}$ in the sediments collected from the Yellow river, China [21]. They reported that the lowest concentration of $\mathrm{Cu}$ was 29.72 $\mathrm{mg} / \mathrm{kg}$ and the highest was $102.22 \mathrm{mg} / \mathrm{kg}$ (Table 4). In Algeria, $\mathrm{Cu}$ was also analyzed in the river sediment collected from the Chelif river and found $102.0 \mathrm{mg} / \mathrm{kg}$ [29]. A comparable concentration of $\mathrm{Cu}$ (135.0 $\mathrm{mg} / \mathrm{kg}$ ) was also found in the sediment of the river Shur, Iran (Table 4) [29]. According to the US EPA (1999), the TRV value for $\mathrm{Cu}$ is $16.0 \mathrm{mg} / \mathrm{kg}$ while the lowest and the highest concentrations of $\mathrm{Cu}$ over the study area were 34.38 and $99.12 \mathrm{mg} / \mathrm{kg}$, respectively, where the respective SEL and TEL values for $\mathrm{Cu}$ are 110.0 and $35.70 \mathrm{mg} / \mathrm{kg}$ (Tables 3 and 4) [27].

Zinc was also analyzed in the collected sediment samples and its respective mean concentrations in the dry, pre-monsoon and post-monsoon were $103.62 \pm 62.74,110.88 \pm$ 95.83 and $55.22 \pm 11.33 \mathrm{mg} / \mathrm{kg}$ (Table 3 ). Results show that site-FS2 was contaminated 
with its highest concentration $(423.28 \mathrm{mg} / \mathrm{kg})$ in the pre-monsoon followed by $297.57 \mathrm{mg} / \mathrm{kg}$ in the dry season, while only $44.32 \mathrm{mg} / \mathrm{kg}$ of $\mathrm{Zn}$ was found in the post-monsoon (Table 3). The high concentration of $\mathrm{Zn}$ at site-SF2 is reasonable because the site-FS2 is just only 3-5 m downstream from the point source. In the pre-monsoon, the river water went to a minimum level compared to that in the dry season, thus pollutants' concentrations are supposed to be maximum in the river water in the pre-monsoon. In Bangladesh, rainfall commonly happens during the pre-monsoon and it goes to its maximum level in the monsoon. Thus, the water level in the water bodies becomes its maximum level, thereby resulting in significant dilution of the contaminants in the monsoon, however, that causes transportation of contaminants from their source points to far away.

Due to rainfall in the pre-monsoon, the waste catalysts washes and/or leaches out by the rain water and falls to the river through the point source. This causes the accumulation of the metals' concentration in the sediments as well as in the river water near the point source. The increasing trend of the concentration of $\mathrm{Zn}$ at the downstream sites, such as from site-FS3 to FS7 (from a point source to downstream) is also suggesting the washing out of the contaminated $\mathrm{Zn}$ from the site-FS2.

Islam et al., also analyzed $\mathrm{Zn}$ in the sediments collected from the Shitalakhya river and its concentration was found to be 200.59 $\mathrm{mg} / \mathrm{kg}$, however, the study area by the Islam $e t$ $a l$., was downstream of the Shitalakhya river that is well-known as a contaminated zone of the riverine system (Table 4) [11]. As mentioned above, the river Buriganga is the most polluted in Bangladesh, consequently, high concentrations of $\mathrm{Zn}$ have been reported by Saha and Hossain [15] and Mohiuddin et al., [13] and the concentrations were 502.30 and $958.15 \mathrm{mg} / \mathrm{kg}$, respectively while Majumder et al., reported only $50.70 \mathrm{mg} / \mathrm{kg}$ of $\mathrm{Zn}$ in the same river's sediments (Table 4) [16]. In our previous study, concentrations of $\mathrm{Zn}$ in the sediments for the same river (Buriganga) were only $36.73 \pm 34.38 \mathrm{mg} / \mathrm{kg}$ for the monsoon and $40.71 \pm 37.33 \mathrm{mg} / \mathrm{kg}$ for the winter (Table 4) [12]. The finding for the low concentrations of the heavy metals in the sediments collected from the river Buriganga has been explained in the preceding sections. The reason for finding the low concentrations of heavy metals is due to dredging the Buriganga river before sampling in our previous study [12]. In a less polluted river (Meghna), Hasan et al., reported a relatively high concentration of $\mathrm{Zn}$ concentration, 79.02 $\mathrm{mg} / \mathrm{kg}$, in the river sediments [17]. Turag and Bangshi are also highly polluted rivers in Bangladesh and concentrations of $\mathrm{Zn}$ in their sediments were found to be 117.15 and 139.48 $\mathrm{mg} / \mathrm{kg}$, respectively (Table 4) $[10,18]$.

Zinc was also analyzed in the sediments collected from many international rivers such as Ganges (India) [25], BT Drainage and Yellow (China) [20,21], Chelif (Algeria) [23], Gediz (Turkey) [24] and Shur (Iran) [29] and its respective concentrations were found to be 10.48-20.40, 89.80-201.88, 164.20-2731.12, 288.0, 40-180 and 250.0 $\mathrm{mg} / \mathrm{kg}$ (Table 4).

Although the mean concentrations of $\mathrm{Zn}$ for the three seasons (dry: $103.62 \pm 62.74$ $\mathrm{mg} / \mathrm{kg}$; pre-monsoon: $110.88 \pm 95.83 \mathrm{mg} / \mathrm{kg}$; post-monsoon: $55.22 \pm 11.33 \mathrm{mg} / \mathrm{kg}$ ) were much lower than the SEL value $(820 \mathrm{mg} / \mathrm{kg})$ while the other reference values such as TEL $(123 \mathrm{mg} / \mathrm{kg})$ and TRV (110 mg/kg) are comparable to that obtained in this study (Table 4). However, concentrations of $\mathrm{Zn}$ at site-SF2 in the dry and pre-monsoon were quite higher than that of TEL and TRV values (Tables 3 and 4). Since site-SF2 is a point source of the ammonia-urea plants, the site 
must be contaminated with the high concentrations of metals.

\section{Correlation Matrix of the Heavy Metals}

The correlation matrix of the heavy metals of interest is shown in Table 5. As seen from Table 5, $\mathrm{Cu}(r=0.880)$ is strongly positively correlated with $\mathrm{Zn}$ that indicates they have the same source. As mentioned above, composites of $\mathrm{ZnO}$ and $\mathrm{CuO}$ have been used as catalysts in the desulfurization of the natural gas in low temperature shift converters of ammonia plants. The positive correlation of $\mathrm{Cr}(r=0.649)$ with $\mathrm{Ni}$ suggests their common source in the study area. Oxides of $\mathrm{Cr}_{2} \mathrm{O}_{3}, \mathrm{NiO}$ and alloy of $\mathrm{Fe}$ with $\mathrm{Cr}$ have also been used as catalysts in the ammonia-urea plant. Therefore, it is concluded that the use of different catalysts such as $\mathrm{ZnO}, \mathrm{CuO}, \mathrm{NiO}$, $\mathrm{Cr}_{2} \mathrm{O}_{3}$, an alloy of $\mathrm{Fe}$ with $\mathrm{Cr}$, etc., in the ammonia-urea plants is the potential source of the heavy metals in the river sediments.

Table 5. Pearson correlation matrix of the heavy metals in the sediments.

\begin{tabular}{cccccc}
\hline $\begin{array}{c}\text { Heavy } \\
\text { metals }\end{array}$ & $\mathbf{M n}$ & $\mathbf{Z n}$ & $\mathbf{C u}$ & $\mathbf{N i}$ & $\mathbf{C r}$ \\
\hline $\mathrm{Mn}$ & 1 & & & & \\
$\mathrm{Zn}$ & 0.130 & 1 & & & \\
$\mathrm{Cu}$ & $0.335^{*}$ & $0.880^{* *}$ & 1 & & \\
$\mathrm{Ni}$ & 0.240 & $0.435^{* *}$ & $0.500^{* *}$ & 1 & \\
$\mathrm{Cr}$ & 0.089 & 0.287 & $0.322^{*}$ & $0.649^{* * *}$ & 1
\end{tabular}

**Correlation is significant at the 0.01 level (2-tailed).

*Correlation is significant at the 0.05 level (2-tailed).

\section{Pollution Assessment of Heavy Metals in the River Sediment}

As mentioned above, most of the sites in the study area were contaminated with elevated concentrations of heavy metals in the dry and pre-monsoon compared to that in the post-monsoon. Accordingly, the mean concentrations of the metals of interest for the dry and pre-monsoon were used to calculate the following statistical indices in order to assess the metals' pollution in the river sediments: geo-accumulation index $\left(I_{\mathrm{geo}}\right)$, contamination factor $\left(C_{\mathrm{f}}\right)$, degree of contamination $\left(C_{\mathrm{d}}\right)$, pollution load index (PLI) and ecological risk potential $\left(R_{\mathrm{I}}\right)$. The values of the indices are shown in Table 6 .

Equations (1), (2) and (3) were used to calculate the values for $I_{\text {geo }}, C_{\mathrm{f}}$ and $C_{\mathrm{d}}$, respectively [8] while eq. (4) was used for PLI [9]. Equation (6) was used to calculate $R_{1}$ value using eq. (5) from where the values for the toxic response factor $\left(T_{\mathrm{r}}\right)$ were obtained $[8,10]$.

According to Muller, the sediment is considered uncontaminated for $I_{\text {geo }} \leq 0$, while that can be regarded as uncontaminated to moderately contaminated for $0<I_{\text {geo }}<0$ [6]. As seen from Table 5, the lowest and the highest values of the $I_{\text {geo }}$ factor are 0.59 and 0.64 , respectively. Accordingly, the study area can be treated as uncontaminated to moderately contaminated.

Industrial wastewater having heavy metals contaminates the water bodies through direct discharge. For the first time, Hakanson [8] and Tomlinson et al., [9] classified the contaminated aquatic sediments into four groups (Table 2).

The contamination factors $\left(C_{\mathrm{f}}\right)$ of the relevant metals, i.e., $\mathrm{Cr}, \mathrm{Mn}, \mathrm{Ni}, \mathrm{Cu}$ and $\mathrm{Zn}$ are less than 1 (ranging from 0.27 to 0.95 ) except for $\mathrm{Cu}$, where the $C_{\mathrm{f}}$ values are more than 1 at all the sites except sites PS1 (0.86) and PS2 (0.88) and the values for $C_{\mathrm{f}}$ are tabulated in Table 6. According to the $C_{\mathrm{f}}$ values, $\mathrm{Cu}$ and $\mathrm{Cr}$ exhibited the highest (1.07) and the lowest (0.27) values among the heavy metals where that for $\mathrm{Zn}, \mathrm{Mn}$ and Ni were $0.95,0.69$ and 0.64 , respectively (Table 6). On the basis of the $C_{\mathrm{f}}$ values for the relevant metals, it is concluded that the sediments of the river Shitalakhya were loaded with low metal's concentrations, however, the $C_{\mathrm{f}}$ values for $\mathrm{Cu}$ were more than 1 at all the sites except 
sites PS1 and PS2 (Tables 1 and 3). According to the Hakanson and Tomlinson et al., classification, the study area was moderately contaminated with $\mathrm{Cu}$ (Table 2). However, a very high $C_{\mathrm{f}}$ value $(>6)$ for $\mathrm{Cu}$ has been reported in the sediments collected from the river Buriganga that indicates the high level of contamination of the riverine system with $\mathrm{Cu}$ [15]. In our previous study, we also reported that the sediments of the Buriganga river were contaminated with $\mathrm{Cu}$ [12]. It is reasonable to find the high $C_{\mathrm{f}}$ values for $\mathrm{Cu}(1.07)$ and $\mathrm{Zn}$ (0.95) among the relevant heavy metals because of using the composites of $\mathrm{ZnO}$ and $\mathrm{CuO}$ as catalysts in the ammonia-urea plants for a long time. Leaching out and/or wash out of the waste catalysts by the rain water cause the respective metals' pollution in the riverine system.

The values of the degree of contamination $\left(C_{\mathrm{d}}\right)$ for $\mathrm{Cr}, \mathrm{Mn}, \mathrm{Ni}, \mathrm{Cu}$ and $\mathrm{Zn}$ are tabulated in Table 6 . The highest $C_{d}$ value was observed at site-FS2 $\left(C_{\mathrm{d}}, 5.90\right)$ while the lowest was at site-PS2 $\left(C_{\mathrm{d}}, 2.86\right)$ and an order was made for the remaining sites on the basis of $C_{\mathrm{d}}$ values: FS3 $>$ FS4 $>$ FS6 $>$ CS1 $>$ PS3 $>$ FS5 $>$ FS1 $>$ CS2 $>$ FS $7>$ CS3 $>$ PS1 (Table 6). The high $C_{\mathrm{d}}$ value at site-FS2 is reasonable. This is because the site-FS2 is just 3-5 $\mathrm{m}$ downstream from the point source of the ammonia-urea plants (Table 1). Since the highest value of $C_{\mathrm{d}}$ is 5.90 , i.e., $C_{\mathrm{d}}<8$, thus the study area was contaminated with low concentrations of the metals of interest (Table 2). However, in the previous study, the $\mathrm{Cd}$ value was found to be 33.16 for the sediments of the river Buriganga [15].

The pollution load index (PLI) for the metals of interest was also calculated in order to assess the pollution status in the sediments of the Shitalakhya river. The relevant study area is regarded as polluted when PLI $>1$ (Table 2) [9]. On the basis of the present results, it is suggested that the study area (Shitalakhya river) was polluted with low concentrations of heavy metals because of the PLI value of less than 1 (Table 6).

Ecological risk potential $\left(R_{\mathrm{I}}\right)$ was calculated from the individual ecological risk factor $\left(E_{\mathrm{r}}\right)$ for the individual metals of interest to assess the contamination status that might cause ecological risk in the study area. The low value of R1 (8.81) indicates that the study area was with a low ecological risk (Table 6). This is because as $\mathrm{R} 1<150$, the relevant study area should be regarded as a low ecological risk potential [8].

Table 6. Contamination factor $\left(C_{\mathrm{f}}\right)$, degree of contamination $\left(C_{\mathrm{d}}\right)$, pollution load index $(\mathrm{PLI})$ and ecological risk potential $\left(\boldsymbol{R}_{\mathrm{f}}\right)$.

\begin{tabular}{|c|c|c|c|c|c|c|c|c|c|c|c|c|c|c|c|c|c|}
\hline \multirow{3}{*}{ Heavy Metals } & \multicolumn{14}{|c|}{ Contamination factor $\left(C_{\mathrm{f}}\right)$} & \multirow{3}{*}{$\begin{array}{c}\text { Toxic } \\
\text { response } \\
\text { factor } \\
\left(T_{\mathrm{r}}\right) \\
\end{array}$} & \multirow{3}{*}{$\begin{array}{c}\text { Potential } \\
\text { ecological } \\
\text { risk factor } \\
\left(E_{\mathrm{r}}\right) \\
\end{array}$} & \multirow{3}{*}{$\begin{array}{c}\text { Geo- } \\
\text { accumulation } \\
\text { index }\left(I_{\text {geo }}\right)\end{array}$} \\
\hline & \multicolumn{14}{|c|}{ Sampling sites } & & & \\
\hline & FS1 & $F S 2$ & FS3 & FS4 & FS5 & FS6 & FS7 & CS1 & CS2 & PS1 & PS2 & $P S 3$ & CS3 & Mean & & & \\
\hline $\mathrm{Cr}$ & 0.25 & 0.31 & 0.30 & 0.32 & 0.29 & 0.28 & 0.26 & 0.25 & 0.28 & 0.25 & 0.20 & 0.24 & 0.24 & 0.27 & 2 & 0.54 & 0.59 \\
\hline $\mathrm{Mn}$ & 0.82 & 0.78 & 0.87 & 0.70 & 0.70 & 0.63 & 0.66 & 0.67 & 0.66 & 0.64 & 0.45 & 0.61 & 0.72 & 0.69 & 1 & 0.69 & 0.64 \\
\hline $\mathrm{Ni}$ & 0.60 & 0.69 & 0.71 & 0.69 & 0.68 & 0.67 & 0.62 & 0.62 & 0.68 & 0.55 & 0.57 & 0.66 & 0.64 & 0.64 & 2 & 1.28 & 0.62 \\
\hline $\mathrm{Cu}$ & 1.06 & 1.44 & 1.19 & 1.19 & 1.00 & 1.12 & 0.98 & 1.10 & 1.06 & 0.86 & 0.88 & 1.11 & 0.86 & 1.07 & 5 & 5.35 & 0.61 \\
\hline $\mathrm{Zn}$ & 0.70 & 2.68 & 0.92 & 0.98 & 0.80 & 0.90 & 0.78 & 0.87 & 0.74 & 0.63 & 0.76 & 0.87 & 0.68 & 0.95 & 1 & 0.95 & 0.64 \\
\hline $\begin{array}{l}\text { Degree of } \\
\text { contamination } \\
\left(C_{\mathrm{d}}\right)\end{array}$ & 3.43 & 5.90 & 3.99 & 3.88 & 3.47 & 3.60 & 3.30 & 3.51 & 3.42 & 2.93 & 2.86 & 3.49 & 3.14 & 3.62 & & & \\
\hline $\begin{array}{l}\text { Pollution load } \\
\text { index (PLI) }\end{array}$ & 0.02 & 0.13 & 0.04 & 0.04 & 0.02 & 0.02 & 0.02 & 0.02 & 0.02 & 0.01 & 0.01 & 0.02 & 0.01 & - & & & \\
\hline $\begin{array}{l}\text { Index of } \\
\text { ecological risk } \\
\text { potential }\left(R_{\mathrm{I}}\right)\end{array}$ & & & & & & & & & & & & & & & & 8.81 & \\
\hline
\end{tabular}




\section{Conclusion}

In the present study, concentrations of the metals of interest, i.e., $\mathrm{Cr}, \mathrm{Mn}, \mathrm{Ni}, \mathrm{Cu}$ and $\mathrm{Zn}$ in the surface sediment of the river Shitalakhya were found to be lower than the reference values except for $\mathrm{Mn}$, where the mean concentrations ranging from $567.02 \pm$ 17.01 to $612.59 \pm 15.31 \mathrm{mg} / \mathrm{kg}$ for the three seasons, were exceeded the reference values. In accordance with the low values of the statistical indices such as geo-accumulation index $\left(I_{\text {geo }}\right)$, contamination factor $\left(C_{\mathrm{f}}\right)$, degree of contamination $\left(C_{\mathrm{d}}\right)$, pollution load index (PLI) and ecological risk potential $\left(R_{\mathrm{I}}\right)$ factors, it is suggested that the study area was low contaminated with the relevant metals. However, in the dry and pre-monsoon, the concentrations of $\mathrm{Ni}$ and $\mathrm{Cu}$ exceeded the recommended values such as TRV and TEL, while $\mathrm{Cr}(31.58 \mathrm{mg} / \mathrm{kg})$ exceeded only the TRV $(26.0 \mathrm{mg} / \mathrm{kg})$ in the pre-monsoon. On the basis of the statistical indices found in this study, it is, therefore, concluded that the aquatic environment of the Shitalakhya river was with low ecological risk. However, the high concentrations of $\mathrm{Ni}$ and $\mathrm{Cu}$ in the river sediments may cause ecological risk in the riverine system. The high concentration of $\mathrm{Ni}$ and $\mathrm{Cu}$ in the river sediments may be due to leach out and/or wash out of the dumped catalysts by rainwater.

\section{Acknowledgement}

The authors acknowledge to the Ministry of Science and Technology, People's Republic of Bangladesh for financial support to carry out this work under the project "Monitoring and source identification of persistent toxic substances in atmospheric and biotic environment in Bangladesh".

\section{Declaration of Competing Interest}

The authors declare that they have no known competing financial interests or personal relationships that could have appeared to influence the work reported in this paper.

\section{Conflict of Interest}

The authors declare that there is no conflict of interest.

\section{References}

1. M. A. H. Khan, Environmental aspects of surface water development projects in Bangladesh. In: Environment and development in Bangladesh, edited by A Atiq Rahman, (1994). Publisher, country

2. Department of Environment (DoE), The People's Republic of Bangladesh, Agargaon, Dhaka, Bangladesh, (1997).

3. S. Ashraf, N.B. Rizvi, A. Rasool, T. Mahmud, G.G. Huang and M. Zulfajri, Groundw. Sustain. Dev., 11 (2020) 100428.

doi: 10.1016/j.gsd.2020.100428

4. K. Ershad, A River in Distress. A weekly Publication of Daily Star, 13 (2009) 8.

5. ASTM. Standard Practice for Total Digestion of Sediment Samples for Chemical Analysis of Various Metals. Annual book of ASTM standards, 2003.

6. G. Muller, Geo. J., 2 (1969) 108. https://scinapse.io/papers/782739266

7. K. K. Turekian and K. H. Wedepohl, Bull. Geol. Soc. Am., 72 (1961) 175. https://doi.org/10.1130/00167606(1961)72[175:DOTEIS]2.0.CO;2

8. L. Håkanson, Water Res., 14 (1980) 975. https://doi.org/10.1016/00431354(80)90143-8

9. D. L. Tomlinson, J. G. Wilson, C. R. Haris and D. W. Jeffrey, Helgolander Meeresunters, 33 (1980) 566. https://link.springer.com/article/10.1007/ $\underline{\text { BF02414780 }}$ 
10. M. S. Rahman, N. Saha and A. H. Molla, Environ. Earth Sci., 71 (2014) 2293. doi 10.1007/s12665-013-2631-5

11. M. S. Islam, A. K. Ahmed, M. Raknuzzaman, M. H. Al-Mamun and M. Masunaga, Arch. Environ. Contam. Toxicol., 68 (2015) 92. https://doi.org/10.1007/s00244-0140079-6

12. A. Nargis, S. Sultana, M. J. Raihan, M. E. Haque, A. B. M. R. Sadique, M. S. I. Sarkar, M. M. Un Nabie, W. Zhai, M. Cai and A. Habib, Inter. J. Environ. Sci. Technol., 16 (2019) 1663. https://doi.org/10.1007/s13762-018-1822-8

13. K. M. Mohiuddin, Y. Ogawa, H. M. Zakir, K. Otomo and N. Shikazono, Inter. J. Environ. Sci. Technol., 8 (2011) 723. doi: 10.1007/BF03326257

14. M. K. Ahmed, A. C. Bhowmik, S. Rahman and M. R. Haque, Asian J. Water Environ. Poll., 7 (2010) 77. https://content.iospress.com/articles/asia $\underline{\text { n-journal-of-water-environment-and- }}$ pollution/ajw7-1-11

15. P. K. Saha and M. D. Hossain, Assessment of heavy metal contamination and sediment quality in the Burigangariver, Bangladesh. 2nd International Conference on Environmental Science and Technology. IPCBEE, 6, IACSIT Press, Singapore, (2011).

16. R. K. Majumder, B. M. R. Faisal, M. N. Zaman, M. J. Uddin and N. Sultana, Inter. Res. J. Environ. Sci., 4 (2015) 80. http://www.isca.in/IJENS/Archive/v4/i5/ 13.ISCA-IRJEvS-2015-082.pdf

17. M. Hasan, M. A. T. M. Rahman, B. Saha and A. K. I. Kamal, Am. J. Environ. Sci., 11 (2015) 427. doi : 10.3844/ajessp.2015.427.439

18. Z. Banu, A. M. S. Chowdhury, M. D. Hossain and N. Kenichi, J. Water Resour. Prot., 5 (2013) 239. http://dx.doi.org/10.4236/jwarp.2013.52 $\underline{024}$

19. R. Khan, M. S. Islam, A. R. M. Tareq, K. Naher, A. R. M. T. Islam, M. A. Habib, M. A. B. Siddique, M. A. Islam, S. Das, M. B. Rashid, A. K. M. A. Ullah, M. M. H. Miah, S. U. Masrura, M. Bodrud-Doza, M. R. Sarker, A. B. M. Badruzzaman Environ. Nanotechnol. Monit. Manag., 14 (2020) 100318. https://doi.org/10.1016/j.enmm.2020.100 $\underline{318}$

20. M. Das, M. K. Ahmed, M. S. Islam, M. M. Islam and M. S. Akter, Terrest. Aqua. Environ. Toxicol., 5 (2011) 8. http://www.globalsciencebooks.info/Onl ine/GSBOnline/images/2011/TAET_5(1 /TAET 5(1)8-13o.pdf

21. C. Liu, J. Xu, C. Liu, P. Zhang and M. Dai, Bull. Environ. Contam. Toxicol., 82 (2009) 26.

doi: 10.1007/s00128-008-9563-x. Epub $2008 \operatorname{Sep} 20$

22. C. Wang, Z. Niu, Y. Li, J. Sun and F. Wang, J. Zhejiang Univ. Sci. A, 12 (2011) 399. https://doi.org/10.1631/jzus.A1000338

23. M. Belhadj, M. R. Ghezzar, F. Abdelmalek, A. A. Benhamed, B. Ouddane and A. Addou, Fresen. Environ. Bull., 15 (2006) 186.

https://hal.archives-ouvertes.fr/hal$\underline{00326206}$

24. H. Akcay, A. Oguz and C. Karapire, Water Res., 37 (2003) 813. doi: 10.1016/S0043-1354(02)00392-5

25. A. Gupta, D. K. Rai, R. S. Pandey and B. Sharma, Environ. Monit. Assess., 157 (2009) 449. doi: 10.1007/s10661-008-0547-4

26. D. Persuad, R. Jaagumagi and A. Hayton, Guidelines for the protection and management of aquatic sediment quality in Ontario. Ontario Ministry of the Environment, Canada, (1993). 
27. US EPA (US Environmental Protection Agency), Screening level ecological risk assessment protocol for hazardous waste combination facilities. Vol. 3, Appendix E: Toxicity reference values. EPA 530D99-001C, (1999).

http://www.epa.gov/epaoswer/hazwaste/ combust/eco-risk/volume3/appx-e.pdf
28. D. D. MacDonald, C. G. Ingersoll and T. A. Berger, Arch. Environ. Contam. Toxicol., 39 (2000) 20. https://doi.org/10.1007/s002440010075

29. A. R. Karbassi, S. M. Monavari, B. G. R. Nabi, J. Nouri and K. Nematpour, Environ. Monit. Assess., 147 (2008) 107. doi: 10.1007/s10661-007-0102-8. 